\author{
Mariusz Borysiewicz \\ (Pomeranian University in Slupsk) \\ https://orcid.org/0000-0002-8207-557X
}

\title{
The Economic Achievements of Polish Diaspora in Manchuria and Inner Mongolia, 1898-1936*
}

\author{
Osiqgnięcia gospodarcze polskiej diaspory w Mandżurii i Mongolii Wewnętrznej \\ w latach 1898-1936
}

\begin{abstract}
For a century and a half the Far East, including Inner Mongolia and Manchuria was the scene of endless wanderings and long sojourns of political exiles from Poland, whom Russian tyranny drove into that wilderness, and many of whom made significant contri-

* The article is dealing mainly with Polish entrepreneurs, employers and traders, mainly conducting their business activities from the last decade of the nineteenth century to the midthirties of the twentieth century within the borderland between Russia, Inner Mongolia and North China. At that time, Polish entrepreneurialism was at the peak of its potential in the region. What followed next, however, was the rapid downfall of the local Polish community, accompanied by a drastic decline of the role played by major Polish merchants and industrialists, who were eventually replaced by Japanese businessmen and manufacturers. (Archiwum Archidiecezjalne w Gnieźnie [hereinafter: AAG], Archiwum Prymasa Polski [hereinafter: APP], ref. no. 65, p. 480). The issue of Polish involvement in Manchurian and Inner Mongolian economy as well as industry after 1936 requires further research. Unfortunately, there are limited traces of business activities undertaken by members of Polish enclave in the late 1930s and 1940s. Most of them can be found in Polish press that was issued in Harbin, especially in the shape of advertisements and commercials targeted towards small artisans, craftsmen and shopkeepers ('Tygodnik Polski' 18 V 1941, 20, p. 4; 'Tygodnik Polski' 25 V 1941, 21, p. 2; 'Ojczyzna. Niezależny Tygodnik Demokratyczny' 16 XII 1945, 1, p. 4). Thus, little is known about the Poles who set up or continued businesses, taking on financial risks in the hope of profit, after 1936 when Japan had strengthened its grip over Manchuria ('Plan for Key Industries', Manchuria: A Semi-monthly Publication of the Manchuria Daily News, vol. 1, 1936, p. 180). Moreover, this paper presents historical and geopolitical context which, in time, gave rise to the economic accomplishments of Poles in Manchuria and Inner Mongolia. Nevertheless, the article is not meant to cover all subjects connected with the functioning of the local Polish diaspora that had existed there for more than half a century.
\end{abstract}


butions to the economic development of that part of Asia. In the course of time numerous Poles - partly political exiles and partly voluntary emigrants, being gifted with a spirit of enterprise - built up large industrial undertakings and made great fortunes, both in sparsely populated steppes of Inner Mongolia and vast forests of Northeastern China. Such were, for instance, the industrialist Władysław Kowalski (1870-1940) and the mining engineer Kazimierz Grochowski (1873-1937). Both of them were prominent representatives of the Polish diaspora in Manchuria and Inner Mongolia.

Kowalski, widely respected by other diasporas in the area, made millions in business and became one of the most influential manufacturers as well as philanthropists across Manchuria. Grochowski, on the other hand, supervised the geological survey on the Amur, on Sakhalin and in Inner Mongolia, and found petroleum in Manchuria. The presence of Polish community in Manchuria and Inner Mongolia cannot be separated from the Russian-built Chinese Eastern Railway that linked Siberia with North China and drew people from the far reaches of the Tsarist Russia in their tens of thousands to the largely wild and uncharted region in the borderland between Russia, Inner Mongolia and Manchuria.

Key words: Polish Diaspora, Manchuria, Inner Mongolia, entrepreneurship, economy

For a century and a half the Far East, including Mongolia and Manchuria, was the scene of endless wanderings and long sojourns of political exiles from Poland, whom Russian tyranny drove into the wilderness, and many of whom made significant contributions to the economic development of that segment of the Asian continent ${ }^{1}$. In the course of time numerous Poles - partly political exiles and partly voluntary emigrants, being gifted with a spirit of enterprise - built up large industrial undertakings and made great fortunes both in sparsely populated steppes of Inner Mongolia and vast forests of Northeastern China ${ }^{2}$. There were several historical currents at work in the past that contributed to a steady influx of European merchants, traders and entrepreneurs into the borderland region between Tsarist Russia and Qing China, which encompassed, inter alia, the area of Manchuria and Inner Mongolia ${ }^{3}$.

In the seventeenth century, the Russians were gradually pushing towards Chinese Empire by way of Siberia. Because of that, the Sea of Okhotsk was reached by Russian hunters early in the next century. No sooner had the Amur River been navigated than Kamchatka was explored and a treaty was concluded with the rulers of China. In 1768 and the following years, an organized exploration of the eastern reaches of the whole of Imperial Russia was undertaken ${ }^{4}$. The climax of these processes of

\footnotetext{
$1 \quad$ R. Dyboski, L. Krzyżanowski, Poland in World Civilization, New York 1950, p. 107.

2 K. Grochowski, Polacy na Dalekim Wschodzie, Harbin 1928, pp. 157-158.

3 Centralne Archiwum Wojskowe [hereinafter: CAW], Oddział II Sztabu Głównego (Generalnego) z lat 1921-1939 [hereinafter: Od. II Szt. Gł.], ref. no. I.303.4.5515, pp. 2-3.

4 J. Scott-Keltie, O.J.R. Howarth, History of Geography, London 1913, p. 72.
} 
colonization was attained, just as in the case of California, when Russians reached the Pacific coast and founded the city of Vladivostok ${ }^{5}$. In order to secure the North China markets for Russian merchants and businessmen, Tsarist government was determined to wrest Mongolia and Manchuria from China. Fortunately for the Russians, both Inner Mongolia ${ }^{6}$ and Manchuria ${ }^{7}$ were only sparsely populated, mostly by local tribes, and less important from the political point of view, whereas the Western invasion took place in the very heart of China ${ }^{8}$.

For the first half of the twentieth century, Manchuria and - to a lesser extent - Inner Mongolia, were the prize in battles between China, Japan and Russia9. In the end, Russia had failed to yoke Manchuria to eastern Siberia. Japan, on the other hand, tried shaping it into the toehold for its imperial dream of the 'Greater East Asia Co-Prosperity Sphere', which was described as 'an international order based upon common prosperity' and as a device for 'the development of the Japanese race ${ }^{\prime 10}$. The Chinese

5 Bureau of Foreign Commerce, Commercial Relations of the United States with Foreign Countries during the Year 1908, vol. 2, Washington 1909, p. 626.

6 Up until the end of the seventeenth century, almost all residents in Inner Mongolia were Mongols. The law of the Qing dynasty prohibited the Han people to enter Mongolia. By the mid-eighteenth century, a few Han Chinese peasants were employed by Mongolians in the border areas to engage in farming. Han migration had gradually increased since the nineteenth century. The Han population, however, was still smaller than that of the Mongols and was concentrated in a few southern regions. With the advent of the twentieth century, the central government encouraged Han migration to Mongolia and forced certain Mongols to give up their land. Han migration increased rapidly and its total number soon became twice the size of the Mongolian population. However, until the 1940s, the Han people were still concentrated in the southern agricultural areas and there were very few Han Chinese in other parts of Inner Mongolia (L. Bazylow, Historia Mongolii, Wrocław 1981, pp. 184-204; S.C. M. Paine, Imperial Rivals. China, Russia, and Their Disputed Frontier, Armonk 1996, p. 280).

7 This situation was rooted in the Manchu's hold on the Northeast of China, which their emperors had attempted to maintain as a cultural reserve. Nevertheless, countermanding centuries of edicts restricting migration to Manchuria, Han Chinese homesteaders flooded the region. Between 1927 and 1929 alone, an estimated one million settlers arrived each year, surpassing the number of Europeans who landed annually in the United States at the peak of its immigration wave. At the same time, more Manchu lived on the south of the Great Wall than in their former homeland, and they had culturally assimilated with the Han Chinese they once ruled (J. Stephan, The Russian Far East. A History, Stanford 1994, pp. 72-79; M. Meyer, In Manchuria: A Village Called Wasteland and the Transformation of Rural China, New York 2015, pp. 3-4).

8 S.A. Korff, Russia in the Far East, Washington 1921, pp. 10-11.

9 Г. Трубецкой, Китай, Япония и Россия, 'Московский еженедельник' 1909, 37, pp. 7-20.

10 Propaganda Corps, Imperial Japanese Forces, Significance of Greater East Asia Co-Prosperity Sphere, Manila 1942, pp. 2-18; Office of Strategic Services, Research and Analysis Branch, The Greater East Asia Co-Prosperity Sphere, 'Current Intelligence Study' 10 VIII 1945, 35, p. 1. 
managed to regain a firm control of Manchuria after Soviet advisers withdrew from the region in 1955 and therefore it came under the sole supervision of the central government in Beijing ${ }^{11}$. At that time, various movements for autonomy in Inner Mongolia came under strict control of the Chinese Communist Party ${ }^{12}$.

Until 1905, Russian Empire occupied a privileged position in Manchuria. Russians seized the opportunity to extend their influence in Northern China by creating a new railway infrastructure, namely, a semi-colonial Chinese Eastern Railway ${ }^{13}$ and a number of settlements along the railway's right-of-way zone ${ }^{14}$. The single-track line was meant to provide a shortcut for the world's longest railroad, the Trans-Siberian Railway ${ }^{15}$, from near the Siberian city of Chita, across northern Inner Manchuria through Harbin to the Russian port of Vladivostok ${ }^{16}$. Furthermore, both Russia and Japan struggled with the policy of whether to annex Manchuria and Inner Mongolia or leave them in present condition and simply pour more forces into the region. For instance, Nicholas Steinfeld, Director of the Russian Chamber of Commerce in Harbin, advocated vigorously that Russia join hands with Japan and divide Manchuria, as a protection against Japanese economic exploration of Northern Manchuria ${ }^{17}$. Russian government, on the contrary, was more circumspect and cautious ${ }^{18}$. All these considerations lost their meaning when the Japanese took complete control of Manchuria and Inner Mongolia in $1931^{19}$ and, less than a year later, created the puppet state of Manchukuo ${ }^{20}$.

Initially, the region was seized by Japan after the Mukden Incident and a pro-Japanese government was installed the following year, exactly on 18th February 193221, with Puyi (1906-1967), the last Qing emperor, being the nominal regent and emperor. Manchukuo's government was abol-

11 N.S. Khrushchev, S. Khrushchev, Memoirs of Nikita Khrushchev, 1953-1964, vol. 3, Statesman, Providence 2007, p. 434.

12 L. Bazylow, op. cit., p. 182.

13 H.K. Tong, Facts about the Chinese Eastern Railway Situation, Harbin 1929, p. 15.

14 D. Ben-Canaan, F. Grüner, I. Prodöhl, Entangled Histories. The Transcultural Past of Northeast China, New York 2014, pp. 17-18.

15 J. Gieysztor, Kolej Syberyjska, 'Kraj' 14 V 1897, 18, pp. 2-6.

16 M. Moustafine, Secrets and Spies. The Harbin Files, London 2002, p. 10.

17 Н.П. Штейнфельд, Мьи и японияь в Маньчжурии, Харбин 1913, pp. 38-46.

18 Н.П. Штейнфельд, Что делать с Маньчжурией?, Харбин 1913, рр. 2-15;

B. De Siebert, G.A. Schreiner, Entente Diplomacy and the World: Matrix of the History of Europe, 1909-1914, London 1921, pp. 24-26.

19 M.H. Lin, International Law and the Undeclared War, New York 1937, p. 7.

20 J.A.B. Scherer, Manchukuo. A Bird's-eye View, Tokyo 1933, p. 70.

21 H. Hussey, Manchukuo in Relation to World Peace. Things Not Told in the Report to the Commission of Enquiry, Geneva 1932, p. 62. 
ished in 1945 after the defeat of Imperial Japan at the end of the Second World War. The territories formally claimed by the puppet state were first seized in the Soviet invasion of Manchuria in August 1945 and then officially transferred to the Chinese administration in the upcoming year ${ }^{22}$. With Japanese investment and rich natural resources, the area became an industrial powerhouse. Thus, Manchukuo had its own issued banknotes, postage stamps and banks ${ }^{23}$. However, European companies were consequently eliminated from the Manchurian market ${ }^{24}$. The worst moment for the Western entrepreneurs, including Polish businessmen, occurred when the Japanese deprived them of timber and mining concessions in the areas of Northern Manchuria and Inner Mongolia ${ }^{25}$. In a similar way, westerners lost their industrial factories and enterprises.

During the period of Russian involvement in the region, quickly followed by Japanese expansion and domination ${ }^{26}$, Manchuria became one of the few really prosperous ind ustrialized regions in the Far East as well as Northern China ${ }^{27}$. The Japanese were content with making Manchuria an immense reservoir of raw materials, including rich coking coal, copper and iron, for industries in Japan ${ }^{28}$. Russian policy, in contrast, created a situation in which Manchuria was a desirable destination for manufacturers and businessmen, including the Poles, from Europe, North America and western reaches of the Russian Empire ${ }^{29}$. By then, the northeastern corner of present-day China was commonly described as Manchuria ${ }^{30}$ by the

22 W. Skóra, Placówki MSZ Drugiej Rzeczypospolitej w Harbinie w latach 1920-1941 na tle dziejów Chin i Mandżurii (Mandżukuo). Szkic do problemu, in: Na szlakach dwóch światów. Studia ofiarowane Profesorowi Jerzemu Hauzińskiemu w 45 lecie pracy naukowej i dydaktycznej, ed. A. Teterycz-Puzio, Słupsk 2016, pp. 683-684.

23 CAW, Od. II Szt. Gł., ref. no. I.303.4.3145, pp. 685-686.

24 Archiwum Akt Nowych [hereinafter: AAN], Ministerstwo Spraw Zagranicznych [hereinafter: MSZ], ref. no. 5413, p. 3.

25 CAW, Od. II Szt. Gł., ref. no. I.303.4.2015, p. 7.

26 S.K. Hornbeck, Contemporary Politics in the Far East, New York 1916, p. 210.

27 Y. Chang, The Economic Development and Prospects of Inner Mongolia (Chahar, Suiyuan, and Ningsia), Shanghai 1933, p. 55.

28 V.A. Yakhontoff, Eyes on Japan, New York 1936, p. 110.

29 C.W. Young, Japanese Jurisdiction in the South Manchuria Railway Areas, Baltimore 1931, pp. 33-40.

30 Due to its similarity to Manchukuo, the name of the puppet state founded by Imperial Japan in 1932, the term Manchuria became obsolete after Japan's surrender, the event which ended the Second World War. However, the word Manchuria long predates the Japanese invasion, appearing on nineteenth-century Chinese and Japanese maps as well as in European atlases, usually replacing the term Tartary (W. Doleżan, Mandżurya. Opis kraju i ludzi, Warszawa 1904, p. 7; H.A. Giles, China and the Manchus, Cambridge 1912, p. 8; M.C. Elliott, The Limits of Tartary: Manchuria in Imperial and National Geographies, 'The Journal of Asian Studies', 59, 3, August 2000, p. 605). 
non-Chinese, from the fact that the area in question was the home of the Manchu tribesmen who established the Manchu or Qing Dynasty which ruled in China from 1644 to 1912. The Chinese, however, referred to this region as the 'Three Eastern Provinces' ('Tung San Sheng'), because of its administrativedivisioninto the threeprovinces of Liaoning, formerly known as Fengtien, in the South, Kirin in the East and Heilungkiang in the North. The eastern border of Manchuria was marked by the Korean Peninsula ${ }^{31}$.

West of Manchuria was Mongolia, the vast area which stretched north of the Chinese Wall and south of Siberia. This territory was formerly divided $^{32}$ in common usage into 'inner' and 'outer' Mongolia ${ }^{33}$. Inner Mongolia was a belt lying directly north of what was occasionally called China proper, from Manchuria on the East to Chinese Turkestan on the West $^{34}$. Outer Mongolia was located on the north of this area and along the Siberian frontier. The eastern ends of both Inner and Outer Mongolia, abutting on Manchuria, had extremely close administrative and economic connections with Manchuria ${ }^{35}$. Therefore, this area formed a hinterland of Manchurian affairs, including foreign concessions and business activity. Economic problems existing at that time in Manchuria, to a certain extent, extended into Inner and Outer Mongolia ${ }^{36}$.

Prior to the establishment of the Kuomintang Nationalist Government in China in 1928, Inner Mongolia was divided for administrative purposes into three special administrative areas. From east to west these were Jehol, Chahar and Suiyuan ${ }^{37}$. One of the early acts of the new Chinese administration was to give those areas the full status of provinces, retaining

31 E. Grabowski, Rozwój zaludnienia w Polsce w zestawieniu z innemi krajami. Według spisu z dnia 30-go września 1921 roku, Warszawa 1922, p. 20.

32 The division between Outer and Inner Mongolia was introduced only when the Qing dynasty began ruling the Mongols. In 1911, Outer Mongolia launched an independence movement, to which responded many leagues and banners of Inner Mongolia. At that time, the campaign was brutally suppressed by the Chinese. In 1921, Outer Mongolia again became independent. There were several attempts by the Inner Mongolians to achieve independence, but all failed. After founding of the People's Republic of China in 1949, Inner Mongolia became an autonomous region of China (W. Dynowski, Współczesna Mongolia, Wrocław 1968, pp. 61-62).

33 E. Stanford, Atlas of the Chinese Empire Containing Separate Maps of the Eighteen Provinces of China Proper and the Four Great Dependencies, London 1908, p. 22.

34 O. Lattimore, Studies in Frontier History: Collected Papers, 1928-1958, London 1962, p. 184.

35 Н.П. Штейнфельд, Русская торговля в Монголии в характеристике местного купечества, 'Вестник Азии' 1909, 2, рр. 112-129.

36 Н.П. Штейнфельд, Причинь упадка русской торговли в Монголии, ‘Промышленность и торговдя' 1911, 21, рр. 361-363.

37 W. Yust, Britannica Book of the Year 1944, London 1944, p. 451. 
the names but making minor boundary changes. Thus, technically, Inner Mongolia had ceased to exist, and the term Mongolia back then referred only to what formerly was known as Outer Mongolia. Practically, the region in question remained closely connected with Manchuria ${ }^{38}$. The Republic of China reorganized Inner Mongolia in such a way that Hulunbuir - an area with substantial groups of Polish entrepreneurs and mining concession holders, such as Kazimierz Grochowski - stayed within Heilongiiang in Manchuria, which had become a province ${ }^{39}$.

The actual history of Polish community in Manchuria along with Inner Mongolia and its economic achievements is inseparably connected with the topic of the Russian-built Chinese Eastern Railway that linked Siberia with Northeastern China ${ }^{40}$. Unfortunately, the contribution of Poles to the creation of the railway line and the city of Harbin - founded by a Polish engineer, Adam Szydłowski on 16th May $1898^{41}$ - remains largely unnoticed. In fact, a considerable contingent of Polish engineers, architects and builders ${ }^{42}$, presumably $30 \%$ of all the staff involved in the construction ${ }^{43}$, founded the building, administrative, political and economical center of that railway ${ }^{44}$ which later on developed into a multinational metropolis and the cradle of Polish diaspora in Manchuria and Inner Mongolia ${ }^{45}$. The first mayor of Harbin was Eugeniusz Dynowski ${ }^{46}$, later a long-time deputy mayor of the city ${ }^{47}$. During the dynamic years, involving construction works on the Chinese Eastern Railway, the number of Polish specialists, officials, physicians, businessmen, clerks, railwaymen and skilled workers

38 Y. Sakatani, G. Clark, Manchuria: A Survey of Its Economic Development, New York 1932, p. 265.

39 E. Kajdański, Fort Grochowski, Olsztyn 1982, p. 136.

40 CAW, Od. II Szt. Gł., ref. no. I.303.4.2726, pp. 5-7.

41 AAN, Kolonia Polska w Mandżurii [hereinafter: KPM], ref. no. 66, p. 7.

42 Г.В. Мелихов, Маньчжурия далекая и близкая, Москва 1991, р. 76.

43 A. Winiarz, Główne kierunki i formy aktywności Polaków w Mandżurii w latach 1897-1949, in: Polskie ślady na Dalekim Wschodzie. Polacy w Harbinie, ed. A. Furier, Szczecin 2008, p. 28.

44 For a detailed history of Polish contribution to Chinese Eastern Railway, see: E. Kajdański, Korytarz. Burzliwe dzieje Kolei Wschodniochińskiej 1898-1998, Warszawa 2000, pp. 30-66.

45 M. Cabanowski, Tajemnice Mandżurii. Polacy w Harbinie, Warszawa 1993, p. 11; H. Kuromiya, A. Pepłoński, Między Warszawa a Tokio. Polsko-japońska wspótpraca wywiadowcza 1904-1944, Toruń 2009, p. 315.

46 At the outset, Harbin's town council was dominated by Poles and Germans. The magistrate adopted a key plan for the construction of Harbin, which was developed by Polish engineer, Konstanty Jokisz, in the closing months of 1898 (K. Grochowski, op. cit., p. 55; 'Biuletyn Polskiej Izby Handlowej w Harbinie' 1932, 5, p. 3; E. Kajdański, Polacy na Dalekim Wschodzie. Inżynier Kazimierz Grochowski, Czyngis-chan i złoto barona Ungerna, Warszawa 2014, p. 30).

47 M. Kałuski, Polacy w Chinach, Warszawa 2001, pp. 63-64. 
was gradually increasing ${ }^{48}$. Most of them were tempted by the prospect of high wages and a possibility to start a comfortable life in Manchuria ${ }^{49}$.

The whole venture, of strategic importance for Russian Empire ${ }^{50}$, was overseen by the Main Board of the Chinese Eastern Railway Company. The board consisted of six members and was elected by the Tsarist government on 27th December 1896 in Saint Petersburg. What is interesting, between 1896 and 1903, the position of vice president within this institution was held by a Pole, namely, Stanisław Kierbedź, who was responsible for the successful development of the project ${ }^{51}$. Consequently, many Polish engineers, railway workers and specialists, whom Kierbedź knew from the time of works on construction of the Trans-Siberian Railway, found employment in managerial positions both in St. Petersburg as well as Vladivostok, and especially in Manchuria. At that time, many other Poles which were engaged in the operation of the Chinese Eastern Railway occupied equally exposed posts within the ranks of the company. For example, Zenobiusz Aleksander Rugiewicz functioned as a Director of the Main Board in St. Petersburg since $1905^{52}$. Accordingly, Teofil Hirszman, Stefan Offenberg, Karol Weber, Mikołaj Kazi-Girej and Aleksander Łętowski were among the most notable Polish engineers and experts accountable for the expansion of the projected wide-gauge railway line around Harbin ${ }^{53}$.

Over the years, Poles occupied significant positions within the local structures of the Russian authorities in railway's right-of-way zone, related to economy, banking, industry, medicine, administration and the judicial system $^{54}$. However, Polish community was extremely diversified, and consisted mostly of builders of the railway line ${ }^{55}$, people looking for a better

48 'Pamiętnik Charbiński' 1923, 1, pp. 23-24; 'Listy Harbińskie' 1932, 5, p. 2; A. Jabłońska, K. Krąkowski, Z dziejów Polonii harbińskiej, 'Przegląd Orientalistyczny' 1961, 2, p. 161.

49 K. Grochowski, op. cit., pp. 6-15; K.Y. Deog, Kolonia polska w Mandżurii, Kraków 2001, pp. 46-49.

50 G. Krahmer, Syberya i znaczenie wielkiej kolei syberyjskiej, Warszawa 1898, p. 115.

51 'Inżynier Kolejowy' 1926, 8-9, p. 239; E. Kajdański, Wspomnienia z mojej Atlantydy, Kraków 2013, p. 12.

52 'Listy Harbińskie' 1932, 5, p. 2.

53 M. Janik, Dzieje Polaków na Syberii, Kraków 1928, p. 35; K. Symonolewicz, Miraże Mandżurskie, Warszawa 1932, pp. 181-182.

54 J. Tokarski, Przez Syberię, Mandżurię i Japonię do brzegów Oceanu Spokojnego, Lwów 1911, p. 54; W. Theiss, Dzieci syberyjskie. Dzieje polskich dzieci repatriowanych z Syberii i Mandżurii w latach 1919-1923, Warszawa 1992, p. 28.

55 Private collection of Jerzy Czajewski, Selected memories from the life of Emilia Czajewska, manuscript written by Emilia W. Czajewska, August-October 1980, pp. 1-2; Private collection of Leonard Spychalski, Story of my Harbin, manuscript written by 
business environment, such as mining engineer Kazimierz Grochowski (18731937) or industrialist Władysław Kowalski (1870-1940) ${ }^{56}$, the approximately 1,500 refugees from Kolchak's dispersed 5th Siberian Rifle Division ${ }^{57}$, 1920s immigrants, mostly comprised by former workers of the Warsaw-Vienna railway, who reached the region in pursuit of work, and political exiles or their descendants $^{58}$. Besides the soldiers of the Polish 5th Siberian Rifle Division, the Polish colony in Harbin also consisted of veterans of the Russo-Japanese conflict and former conscripts to the Chinese Eastern Railway Guard ${ }^{59}$.

In spite of intensive Russification, the Poles in Manchuria and Inner Mongolia not only preserved their faith and language, but also greatly contributed to the economic development of Northeastern China ${ }^{60}$. After the downfall of the Russian Empire in 1917, the majority of Poles in Harbin decided to apply for Polish citizenship and retained it during the entire existence of Polish community in Manchuria. In 1931, for instance, approximately 1,685 Poles $(82.81 \%)$ residing in Harbin possessed Polish citizenship. Passports of other countries were obtained mainly due to financial reasons. Accordingly, 70 Poles (3.44\%) accepted the citizenship of the Soviet Union, 58 Poles $(2.85 \%)$

Leonard Spychalski, (lack of date), pp. 1-23; A. Winiarz, Polska diaspora w Mandżurii, in: Polska diaspora, ed. A. Walaszek, Kraków 2001, p. 387.

56 CAW, Od. II Szt. Gł., ref. no. I.303.4.4476, pp. 7-8.

57 The Polish 5th Siberian Rifle Division was formed on the Russian territory in 1919 during the First World War, but the unit was attached to the White Russian formations and fought mostly in the Russian Civil War. The core of the division was composed of POWs of the former Austro-Hungarian Army and local Poles. The latter were descendants of Poles forcibly resettled to Siberia after failed November Uprising, January Uprising and other struggles with Imperial Russia. On 22nd December 1919, at Taiga, the Polish Legion made a stand against the Red Army but suffered heavy losses. Most of the once 16,000 men strong division were taken as prisoners of war or died during forced labor in the mines. A group of about 1,500, led by Colonel Kazimierz Rumsza, managed to evade capture and reached Harbin on 21st February 1920 (H. Bagiński, Wojsko Polskie na Wschodzie 1914-1920, Warszawa 1921, pp. 536-598; L.E. Vining, Held by the Bolsheviks. The Diary of a British Officer in Russia, 1919-1920, London 1924, p. 215).

58 AAN, KPM, ref. no. 6, pp. 12-13.

59 The Chinese Eastern Railway Guard Force was established by the Main Board of the Chinese Eastern Railway Company in 1897. Soon, however, the unit was transformed into the Trans-Amur Region of the Border Guard Corps in January 1901. The main objective of the guard was to defend the property and employees of the railway company along its right of way belt in Manchuria. After the conversion into the Trans-Amur Border Guard Corps, the force consisted of 25,000 men (H. Bagiński, Wojsko Polskie na Wschodzie 1914-1920, Warszawa 1921, pp. 78-79; J. Białynia-Chłodecki, Ćwierćwiecze kolonii polskiej $w$ Charbinie na Dalekim Wschodzie, Lwów 1923, p. 5). By then, the unit was under direct jurisdiction of Sergei Witte, Minister of Finance and Chairman of the Council of Ministers of the Russian Empire. Roughly 15\% of all the officers within the Trans-Amur Region of the Border Guard Corps were of Polish origin (K. Grochowski, op. cit., pp. 15-16).

60 AAN, KPM, ref. no. 1, pp. 1-4. 
received Chinese citizenship, while 222 people of Polish origin (10.90\%) declared themselves as stateless ${ }^{61}$. The main pillars of Polish presence in Manchuria as well as Inner Mongolia, apart from the Chinese Eastern Railway, were the Polish Catholic Mission, the Polish Diplomatic Mission ${ }^{62}$, various charity organizations, especially the so-called Polish Tavern (Gospoda Polska), and a large group of private entrepreneurs ${ }^{63}$.

By 1903, Harbin's Polish community had grown to 7,00064. At the same time, Harbin occupied more than 20 square kilometers ${ }^{65}$. At its peak, between 1917 and mid 1920s, the Polish enclave in Harbin numbered over 10,000 people $^{66}$, who enjoyed a relatively peaceful environment on Chinese soil. For a time, many smaller towns and villages along the Chinese Eastern Railway's route additionally encapsulated from 6,000 to 10,000 Polish settlers in Northern Manchuria and Inner Mongolia ${ }^{67}$. Beginning in 1924, the number of Polish citizens in Harbin dropped drastically. Former soldiers and prisoners of war had been repatriated to Poland. However, Poles left Harbin mainly due to declining labor market and the subsequent restrictions imposed on them by successive governments exercising control over the $\operatorname{city}^{68}$. Therefore, Polish population in Manchuria declined to approximately 5,000 settlers in the late $1920 \mathrm{~s}^{69}$.

On the contrary, during the period between 1920s and 1930s, there were over a dozen Polish families living in Inner Mongolia ${ }^{70}$. In 1930, the Polish community in the region comprised a total of only 2,000 pioneers, and roughly half of them stayed in Harbin ${ }^{71}$. After Japan seized Southern Manchuria in 1931 and the outbreak of war in the Pacific, more Polish citizens decided to leave those areas. Between 1935 and 1949, the number of Polish residents of Harbin was steady, coming to approximately 1,500 persons $^{72}$. Until 1958, most of the remaining Poles gradually left

61 AAN, Konsulat Generalny RP w Charbinie [hereinafter: KGRP], ref. no. 5, pp. 1-2.

62 AAN, Prezydium Rady Ministrów [hereinafter: PRM], ref. no. VIII-255, pp. 123-124.

63 J. Neja, Polacy w Mandżurii, 'Biuletyn Instytutu Pamięci Narodowej' 2002, 3, p. 34.

64 AAN, MSZ, ref. no. 10389, p. 5; A. Jabłońska, K. Krąkowski, Z dziejów Polonii harbińskiej, 'Przegląd Orientalistyczny' 1961, 2, p. 160.

65 L. Victoir, V. Zatsepine, Harbin to Hanoi. The Colonial Built Environment in Asia, 1840 1940, Hong Kong 2013, p. 21.

66 В.А. Анучин, Географические очерки Маньчжурии, Москва 1948, р. 39; В.П. Петров, Город на Сунгари, Вашингтон 1984, pp. 8-10.

67 CAW, Od. II Szt. Gł., ref. no. I.303.4.2725, p. 55.

68 A. Aleksandrowicz, Mandżuria, jej przeszłość, teraźniejszość, kraj i ludzie, Warszawa 1937, p. 107.

69 AAG, APP, ref. no. 65 , pp. $2-4$.

70 K. Grochowski, op. cit., p. 138.

71 AAN, MSZ, ref. no. 10389, lack of pagination.

72 'Echo z Dalekiego Wschodu' 1934, 3, p. 17. 
Manchuria and Inner Mongolia to settle in Poland, the United States or Australia ${ }^{73}$.

With great eagerness, the Polish inhabitants of Manchuria and Inner Mongolia established various businesses, such as factories ${ }^{74}$, industrial enterprises, restaurants, import-export offices, workshops, warehouses, bakeries and shops ${ }^{75}$. These with less means, as well as the younger generation, including neophyte entrepreneurs, found employment among the affluent representatives of the community. Those more destitute were assisted, first on an individual basis, and then gradually, by organized churchsupported charitable institutions and societies, including the Roman Catholic Charitable Society (Rzymsko-Katolickie Towarzystwo Dobroczynności), which was set up in $1903^{76}$. Equally helpful was a secular association Polish Tavern $^{77}$. This organization not only provided financial support, but also helped to settle disputes among different members of the Polish community and went as far as developing specific forms of justice, such as the Citizens Jury (Sąd Obywatelski) ${ }^{78}$ and the Court of Honor (Sąd Honorowy) ${ }^{79}$. These legal institutions were usually made up of highly respected individuals with relevant knowledge and a possible interest in the outcome of a given proceeding ${ }^{80}$. In 1927, for example, the Court of Honor was composed of Fr. Gerard Piotrowski, Władysław Kowalski, M. Fabisiak and F. Chmielewski ${ }^{81}$. However, they decided about trivial matters, which raised little controversies.

73 AAN, KPM, ref. no. 66, pp. 103-110; A. Jabłońska, K. Krąkowski, op. cit., p. 171.

74 'Tygodnik Polski' 9 IV 1939, 15, p. 7.

75 'Listy Harbińskie. Numer Noworoczny' 1 I 1932, 1, p. 8.

76 Stowarzyszenia polskie w Charbinie, 'Pamiętnik Charbiński' 1923, 1, p. 18. The Roman Catholic Charitable Society was the first officially recognized Polish association in Harbin and Manchuria. However, the first unofficial Polish society in Harbin, called the Church Committee, was established in 1901. Its main goal was connected with raising funds for construction of a Catholic church in Harbin (K. Grochowski, op. cit., p. 73).

77 The Polish Tavern was a social, cultural and educational association operating in Harbin from 1907 to 1949, although it was initially involved in gastronomy ('Praca. Pismo Postępowe Demokratyczne' 12 V 1918, 8, p. 10). This association initiated the first Polish school, organized language courses for the Polish community and charity fundraising. Further, among other cultural activities, it organized charity balls, and strived at integrating the whole community. The association was divided into several sections dedicated to education, working with youth (Polish Youth Association), culture (Theater Group), and sports (hockey, volleyball, football and yachting teams). The Polish Tavern was the first Polish secular association in Harbin (K. Grochowski, op. cit., pp. 54-62; J. Neja, Harbin jako przestrzeń życia i działalności Polonii mandżurskiej, in: Polskie ślady na Dalekim Wschodzie, pp. 58-65).

78 K. Frycz, Wyrok Sadu Obywatelskiego, 'Listy Polskie z Dalekiego Wschodu' 7 VII 1918, 7, pp. 8-13.

79 AAN, KPM, ref. no. 28, pp. 5-8.

80 AAN, KPM, ref. no. 11, pp. 89-93.

81 K. Grochowski, op. cit., p. 62. 
The Chinese Eastern Railway drew tens of thousands of people from the far reaches of the Tsarist Russia to the largely wild and sparsely populated steppes of Manchuria and Inner Mongolia. Entrepreneurs, merchants and traders came to develop natural resources and provide goods and services in Harbin and other multinational settlements along the railway route ${ }^{82}$. Chinese people from the South were also brought in, usually in large numbers, to work as construction laborers. For the Poles, especially within Imperial Russia, who were confined for more than a century to live under the harsh rule of neighboring empires, Inner Mongolia or Manchuria was the land of opportunity. Eventually, some of them would spread further and become instrumental in the development of Polish companies across the region ${ }^{83}$.

Undoubtedly, the most influential Polish businessman in the Far East, including the vast area of Manchuria and Inner Mongolia, was Władysław Kowalski ${ }^{84}$, who conducted his economic activity under various names, such as Leśne Przedsiębiorstwo W. Kowalskiego (Timber Company of W. Kowalski), V. F. Kovalsky, or simply Yablonia Timber Company ${ }^{85}$. That said, other merchants, entrepreneurs and specialists of Polish origin also had a fair share in the exploration of Manchurian as well as of Inner Mongolian markets and their natural resources ${ }^{86}$. The early years of Harbin's existence were marked with increased activity of Polish entrepreneurs. Thus, Adam Czajewski founded a vodka distillery in Harbin ${ }^{87}$. A family of Polish Karaites, namely Eliasz Łopatto and Abram Łopatto, focused on the tobacco industry and established the first factory of cigarettes, one of the largest in China ${ }^{88}$.

82 R. Dyboski, Siedem lat w Rosji i na Syberii (1915-1921). Przygody i wrażenia, Warszawa 1922, p. 33.

83 W. Komorowski, Daleki Wschód w międzynarodowej polityce gospodarczej, Warszawa 1931, pp. 316-317.

84 K.Y. Deog, op. cit., pp. 47-48.

85 H.T. Montague Bell, H.G.W. Woodhead, The China Year Book 1919, London 1919, p. 101; H.G.W. Woodhead, H.T. Montague Bell, The China Year Book 1921, Tientsin 1922, p. 782; Handel zagraniczny. Zapotrzebowanie towarów dla Mandżurii, 'Tygodnik Handlowy' 6 VI 1924, 23, p. 8.

86 W. Skóra, Sytuacja materialna Polonii mandżurskiej w 1929 roku (w świetle raportu konsula RP Konstantego Symonolewicza), 'Przegląd Orientalistyczny' 2010, 3-4, pp. 125-135.

87 M. Kałuski, op. cit., p. 41.

88 These two wealthy Harbiners of Trakai origin often sent considerable sums of money to support the Polish Karaites of Vilnius and Trakai in the 1920s. In 1936 the group of Polish Karaites in Harbin organized the Society of the Polish Karaites in Manchukuo. The Polish consul agreed to support the Society and helped to register it with the government of the country (M. Kizilov, The Sons of Scripture. The Karaites in Poland and Lithuania in the Twentieth Century, Warsaw 2015, pp. 189-190). 
Moreover, Michał Wróblewski started the first large-scale beer brewery in that region ${ }^{89}$. Wróblewski, a brewer from Pomerania, made a stunning career in Manchuria and became a philanthropist within the Polish community in Harbin. Another company founded by Poles, namely Władysław Kowalski and Dynowski, developed the first steam-driven mills ${ }^{90}$. Furthermore, Bohdan Broniewski built a substantial sugar factory in a small town called Acheng (26 miles east of Harbin) ${ }^{91}$, for which the equipment was supplied by a Polish firm called Szpotański, Borman and Swede, as well as another Polish company, that is, a steam boilers factory owned by Krasiński ${ }^{92}$. Apart from the equipment, many specialists were brought from Poland to work in the sugar company ${ }^{93}$. The cultivation of sugar beet, however, took place in Manchuria ${ }^{94}$. In this way, a group of Polish managers introduced the process, which was previously unknown in China, to the Chinese farmers of the area ${ }^{95}$. Hundreds, if not thousands of Polish entrepreneurs and traders, who operated on a much smaller scale, remain largely unrevealed ${ }^{96}$.

Władysław Kowalski was born on 27th June 1870 in a small village of Podolia ${ }^{97}$. His life was an example of fate shared by many other Poles, who were able to take advantage of favorable conditions for the development of entrepreneurship at the turn of the nineteenth century in Asiatic Russia ${ }^{98}$.

89 Książnica Pomorska [hereinafter: KP], Zbiory specjalne [hereinafter: ZS], ref. no. 3392, pp. 1-12.

90 M. Cabanowski, op. cit., pp. 12-13.

91 S.R. Wagel, Finance in China, Shanghai 1914, p. 488.

92 CAW, Od. II Szt. Gł., ref. no. I.303.4.4476, pp. 7-8; W. Syzdek, Na mandżurskim szlaku, 'Życie Warszawy' 8 I 1988, 1, p. 3.

93 Interestingly, the Acheng Sugar Factory in Harbin, Heilongjiang Province, was China's first sugar company, founded in 1905 by a Polish businessman. Its initial capital amounted to almost 1 million rubles. After 1949, Acheng became a pillar of the planned economy, the largest sugar plant in China, producing 3,000 tons of beet sugar a day. However, it was old, burdened with debt, and unable to compete with more efficient producers. In 1998, Acheng became China's first major bankruptcy, putting 4,500 employees out of work (Y. Cai, State and Laid-off Workers in Reform China: The Silence and Collective Action of the Retrenched, London 2006, p. 80).

94 B.Z. Wojas, Dzieje Polonii Charbinskiej, 'Zeszyty Historyczne' 1974, 30 (250), p. 9.

95 R.K.I. Quested, "Matey" Imperialists: the Tsarist Russians in Manchuria 1895-1917, Hong Kong 1982, p. 211; A. Winiarz, Główne kierunki, p. 34

96 K. Grochowski, op. cit., p. 192; M.R. Ristaino, Port of Last Resort. The Diaspora Communities of Shanghai, Stanford 2001, pp. 29-30.

97 А. Петренко, В.Ф.Ковальский - выдатючийся хозяйственник Маньчжурии, 'На сопках Маньчжурии' 1996, 34, р. 4.

98 Many Poles, partly political exiles and partly voluntary emigrants, being gifted with a spirit of enterprise, built up large industrial undertakings and made great fortunes both in European Russia and in the Russian Far East, such were: Ignacy Jasiukowicz (1847-1914), who became, in 1888, managing director of the South Russian Metallurgical Works on the Dnieper and reorganized them on modern lines; the architect Iwan Żółtowski (1867-1959), 
He came from a family of impoverished petty nobility, which suffered Russian repressions in the aftermath of the January Uprising (1863-1864). In his teenage years, Kowalski was forced to work physically for his own subsistence. In this way, he raised money for a voyage to Vladivostok, where he came via Odessa at the age of twenty-three and quickly found himself among the Polish community ${ }^{99}$.

The wealthiest Pole in Manchuria and Inner Mongolia leased huge forest areas from the Chinese government and conducted extensive business activities ${ }^{100}$. Before coming to Manchuria, Władysław Kowalski worked on the construction of the Ussurian section of the TransSiberian Railway, linking Vladivostok with Khabarovsk ${ }^{101}$, which was about $770 \mathrm{~km}$ long ${ }^{102}$. However, it did not take him long to understand that supplying wood was the most profitable activity. Therefore, he engaged all his efforts in felling the forests across Manchuria. The money gained in this way he gradually invested in the development of his future establishments. In 1911, Kowalski received his first official timber concession from the local authorities and called it Yablonia ${ }^{103}$.

who built some of the most sumptuous modern palatial homes in the residential districts of Moscow; the industrialist Władysław Żukowski (1868-1916), who played a prominent part in the Central Russian Industrial Committee during the First World War; Alfons KoziełfPoklewski (1809-1890), who worked his way up from modest beginnings to ownership of a large portion of the numerous mines and metal works in the Ural mountains; Ignacy Sobieszczański (1872-1952), who owned coal mines in the neighborhood of Irkutsk; and, of course, Władysław Kowalski, who earned millions in business at Harbin (Ignacy Jasiukowicz. Źródła powodzenia, 'Przegląd Techniczny' 4 XII 1913, 49, pp. 641-643; Wspomnienia pozgonne. Ś. p. Władysław Żukowski, 'Przegląd Techniczny' 13 XII 1916, 49/50, p. 462; S. Lubodziecki, Polacy na Syberii w latach 1917-1920. Wspomnienia, 'Sybirak' 1934, 3/4, pp. 5-8; R. Dyboski, L. Krzyżanowski, Poland in World Civilization, New York 1950, p. 106).

99 A. Wełniak, Reemigranci polscy z Mandżurii w Elblagu, 'Rocznik Elbląski' 2009, 22, p. 174.

100 F. Kusiak, Osadnictwo reemigrantów z Mandżurii na ziemiach Polski Zachodniej i Północnej w 1949 roku, 'Sobótka' 1994, 3-4, pp. 241-243.

101 V. Volpicelli, Russia on the Pacific. And the Siberian Railway, London 1899, pp. 333-334.

102 A. Williams, The Romance of Modern Engineering. Containing Interesting Descriptions in Non-Technical Language of the Nile Dam, the Panama Canal, the Tower Bridge, the Brooklyn Bridge, the Trans-Siberian Railway, the Niagara Falls Power Bermuda Floating Dock, Etc., London 1912, p. 156.

103 A small settlement located within the concession, where he built a luxurious residence, hospital, school and library containing books and newspapers imported directly from a distant homeland, became a center of his private life. Kowalski lived there with his wife, Helena Zaharoff, whom he married in 1908, and his two daughters, namely Ada and Victoria (J. Neja, Polski król Mandżurii, 'Wprost' 2003, 9, p. 68). The two-storey villa with a swimming pool as well as a tennis court, built in the neoclassical style, survived to this day and currently serves as a museum of Mao Zedong (J. Wasilewska-Dobkowska, Sztuka Chin, Warszawa 2009, p. 57). 


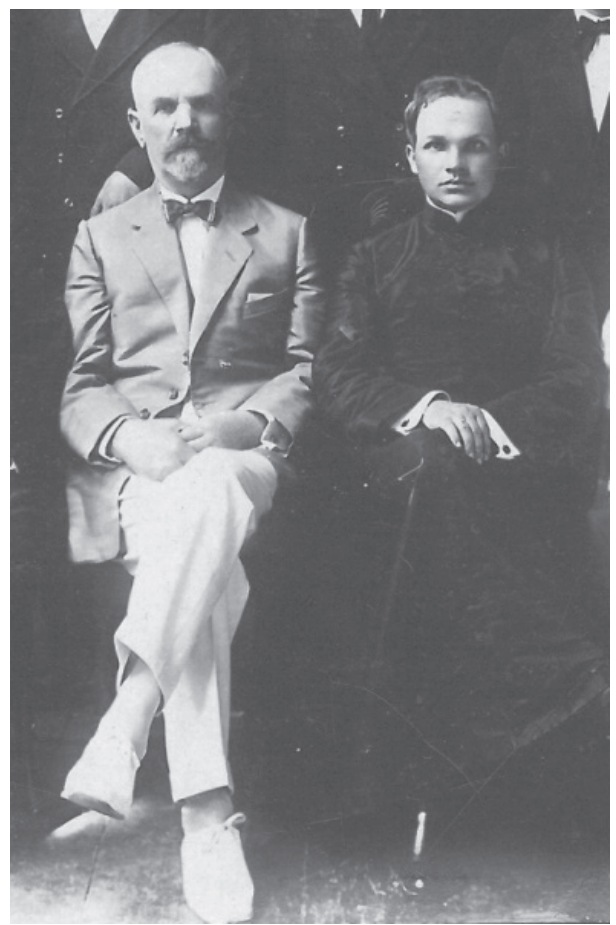

Figure 1: Władysław Kowalski (left) with Fr. Antoni Leszczewicz (1890-1943), Harbin 1920

Source: Private collection of Jerzy Czajewski, President of the Harbiners Club in Szczecin

The concession was located $241 \mathrm{~km}$ east of Harbin ${ }^{104}$. Thus, his company became a major supplier of wood, mainly railway sleepers, not only for the expanding Chinese Eastern Railway infrastructure ${ }^{105}$, but also for the construction entrepreneurs operating within Harbin and smaller towns in the railway's right of way zone ${ }^{106}$.

In 1899, Kowalski, together with Frank and Kiliański, was among the first businessmen who began the timber industry in Manchuria, not to mention Inner Mongolia. In the first decades of the twentieth century, Kowalski became one of the most important contractors of the Chinese Eastern Railway and the richest entrepreneur in North China ${ }^{107}$. From 1903 to 1906, Kowalski was engaged in the construction of several steam flour

${ }^{104}$ H.G.W. Woodhead, H. T. Montague Bell, The China Year Book 1914, London 1914, p. 103.

105 T. Kawata, Glimpses of East Asia, Tokyo 1928, p. 38.

106 J. Rowiński, J. Szczudlik, Z historii kontaktów polsko-chińskich (do 1945 roku), 'AzjaPacyfik' 2005, 8, p. 26.

107 I.A. Mikhoilov, North Manchuria and the Chinese Eastern Railway, Harbin 1924, pp. 181-183; F. Patrikeeff, Russian Politics in Exile. The Northeast Asian Balance of Power, 1924-1931, Oxford 2002, p. 200. 
mills in Harbin ${ }^{108}$. Back then the first place in manufacturing industry across Manchuria was taken by flour-milling ${ }^{109}$. In early 1920s, the railway zone contained in all 35 flourmills, which milled up to 300,000 tons of wheat. At least 24 of these mills were situated in Harbin and approximately six were owned by Władysław Kowalski. Besides flour, his mills produced manna and buckwheat grits. Out of the flour produced, about $2 / 3$ were brought to the CER beltway and the remaining $1 / 3$ was consumed directly at the points where the mills were located ${ }^{110}$.

On the eve of the First World War, Kowalski decided to increase the range of services provided by his company. To this end, he built a veneer factory, the only such a manufacture in Northeast China. Hence, in the mid 1920s, he turned out to be among the most influential manufacturers and exporters of timber and veneer in Manchuria ${ }^{111}$. His timber products were sold on Manchurian market as well as exported to Japan, Australia, North and South America ${ }^{112}$. During the years of the First World War and ongoing conflicts within Russian Empire, the factory was still rapidly expanding. This was possible owing to an excellent work management that was implemented in the leased timber concessions. The whole process was based on a well-developed internal transport network, covering railway lines with a length of nearly $200 \mathrm{~km}^{113}$. The railway system connected different logging zones and sawmills ${ }^{114}$.

Timber concessions ${ }^{115}$ covered an area of approximately $6,157 \mathrm{~km}^{2}$, and stretched along the eastern line of The Chinese Eastern Railway ${ }^{116}$, which

108 Milling in Manchuria, 'American Miller and Processor' 1910, 38, 1-6, p. 309.

109 Milling in Manchuria, 'The Northwestern Miller' 1908, 76, p. 155.

110 Economical Bureau of CER, The Chinese Eastern Railway and its Zone, Harbin 1923, p. 21.

111 'The Timberman' 1927, 28, 7-12, p. 35.

112 J. Neja, Polski król Mandżurii, ‘Wprost' 2003, 9, p. 69.

113 K. Grochowski, op. cit., p. 192.

114 J. Neja, op. cit., p. 68.

115 Konstanty Symonolewicz, Polish consul in Harbin between 1929 and 1930, in his secret report to the Ministry of Foreign Affairs in Warsaw presented the following description of timber concessions belonging to Władysław Kowalski: Yablonia - 2,430 square versts, Imienpo - 450 square versts, Hailin and Hengtaohotzu - 1,030 square versts, and also Mulin -1,500 square versts, which gives a total area of 5,410 square versts (AAN, MSZ, ref. no. 11686, Secret report of Konstanty Symonolewicz, Head of Polish Delegation in Harbin, November 19, 1929, pp. 3-16). After 1835, 1 square verst was estimated at about 1,138 square kilometer (K. Brown, A Biography of No Place. From Ethnic Borderland to Soviet Heartland, Cambridge 2003, p. 242) and therefore a total area of these concessions was approximately $6,157 \mathrm{~km}^{2}$. Most importantly, similar description was given by Kazimierz Grochowski, who stated that the Timber Company of Władysław Kowalski stretched over an area of 5410 square versts (K. Grochowski, op. cit., p. 192).

116 CAW, Od. II Szt. Gł., ref. no. I.303.4.4432, p. 8. 
connected Harbin and Nikolsk-Ussuriysky ${ }^{117}$. At its peak in the beginning of 1925, his company provided employment for almost 10,000 workers across northern parts of Manchuria ${ }^{118}$, including Poles, Russians and the Chinese. Moreover, the reserve stock of timber across his concessions (especially of firs, pines, cedars and oaks) was estimated at nearly one billion cubic feet $^{119}$. This area produced fire-wood, larch wood sleepers, telegraph poles and supporting stanchions for mines. Interestingly, between 1921 and 1924, Kowalski also leased a mining concession from the local government ${ }^{120}$. The scale of his establishment was best evidenced by a wide range of expenses incurred during the initial years of its implementation.

By 1923, Władysław Kowalski had invested a total sum of 10,100,000 dollars in his enterprises within the entire region ${ }^{121}$. Only timber concessions leased by Skidelsky and Popoff, who also tried to expand their ventures into various sectors of Manchurian economy, could match with business carried out by Kowalski. However, they never managed to develop such a wide range of industrial activities ${ }^{122}$.

Many Polish businessmen actively took part in social and cultural life of the Polish colony in Manchuria and Inner Mongolia ${ }^{123}$. In particular, Władysław Kowalski generously sponsored a number of charitable, educational and church organizations, such as the Polish Tavern, actions of the two Polish Catholic parishes as well as Polish Secondary School in Harbin $^{124}$. Soon he became one of the leading figures of the local Polish community ${ }^{125}$. However, economic achievements of Władysław Kowalski in Manchuria were only possible with the patronage and friendship with General Horvath, whom he met in Vladivostok near the end of $1895^{126}$.

117 AAN, KPM, ref. no. 11, lack of pagination.

118 H. Kuromiya, A. Pepłoński, Między Warszawa a Tokio. Polsko-japońska wspótpraca wywiadowcza 1904-1944, Toruń 2009, p. 317.

119 At the time, the reserve stock of timber in North Manchuria was estimated at 136 billions of cubic feet. Out of this quantity only one thirty fourth part (4 billions) was actually exploited (Economical Bureau of CER, The Chinese Eastern Railway and its Zone, Harbin 1923, p. 17; K. Grochowski, op. cit., p. 192).

${ }^{120}$ Economical Bureau of CER, op. cit., p. 18

121 K. Grochowski, op. cit., p. 193.

122 'Journal of the Association of Chinese and American Engineers' 1924, 5, p. 77.

${ }^{123}$ M. Kałuski, Polacy $w$ Chinach, Warszawa 2001, p. 41.

${ }^{124}$ J. Neja, op. cit., p. 69.

125 A. Winiarz, Gtówne kierunki, p. 42.

126 Dimitri Leonidovich Horvath (1859-1937), Director of the Chinese Eastern Railway from 1902 to 1920, was born in Poltava Province, Russia. He was a scion of an old Russian gentry family with Hungarian ancestry. Having been trained as an engineer, he went on to join the army and served in the Russo-Turkish War of 1877-1878 (П.С. Тишенко, Харбинская старина, Харбин 1936, p. 15). His first experience building railways came 
By then, Dimitri Horvath displayed great organizational abilities, and was soon promoted to serve as a head of the Chinese Eastern Railway. At the same time, he sought capable wood suppliers for the rapidly expanding railway infrastructure in the Russian Far East ${ }^{127}$.

After the Bolshevik Revolution of 1917 and decrease of Russian influence in the region, Władysław Kowalski used his Polish passport as a tool of diplomatic immunity for his economic activity. Increasing corruption, lawlessness ${ }^{128}$, and the outburst of a severe worldwide economic depression in $1929^{129}$, which weakened the financial standing of his establishment, led Kowalski to a desperate decision. Thus, he committed several Chinese officials, followed by Japanese profiteers, to the company and ceded half of the company's assets to them in order to solve the financial problems ${ }^{130}$. Soon, however, the greed and predatory policy of his new partners only worsened the situation of the enterprise, which found itself on the verge of bankruptcy in $1930^{131}$. In 1936, the Japanese authorities, despite frequent protests of Polish diplomatic missions in Harbin and Tokyo ${ }^{132}$, took over timber concessions previously awarded to Władysław Kowalski. In the end, Kowalski, bankrupt and brought to a state of extreme nervous exhaustion, died of a heart attack

\footnotetext{
years later, when he was involved in the construction of the Trans-Caspian Railway. In 1895, Colonel Horvath was appointed the director of the Ussurian Railway, which at the time was under construction. Seven years later, he was made the general and chief of the Chinese Eastern Railway (P.S.H. Tang, Russian and Soviet Policy in Manchuria and Outer Mongolia, 1911-1931, Durham 1959, pp. 114-119). As a head of the Chinese Eastern Railway, Horvath was seen by certain officials and military officers as an autocrat, whose political influence in the railway zone lasted for much of his time in that position (L. Maynard, Harbin. General Features, 'Special Consular Reports' 1913, 59, p. 163). In his relations with local population Horvath was homely and democratic. In 1919, for instance, he readily accepted the independence of Poland (E. Kajdański, Wspomnienia z mojej Atlantydy, p. 18). Without his permission, Władysław Kowalski would not be able to become the main contractor of the Chinese Eastern Railway Company (Г.В. Мелихов, Бельй Харбин: Середина 20-x, Москва 2003, р. 76).

${ }_{127}$ H. Shukman, The Blackwell Encyclopedia of the Russian Revolution, Oxford 1988, p. 324.

${ }^{128}$ Efforts of the Timber Company owned by Kowalski were often harassed by the Honghuzi ('Red Beards') bandits. They were nomads who came from China proper and roamed the area around Northern China and the Russo-Chinese border. They raided Russian settlers and plagued Russian troops, mainly during the 1870-1930 era. These bandits were already active around Harbin during the construction of the Chinese Eastern Railway (L.L. Seaman, From Tokio through Manchuria with the Japanese, London 1905, p. 161; K. Symonolewicz, O chunchuzach, ‘Pamiętnik Charbiński' 1924, 2, pp. 17-22; KP, ZS, ref. no. MW 25, p. 5).

129 J.S. Olson, Historical Dictionary of the Great Depression, 1929-1940, Westport 2001, p. 327.

130 A. Winiarz, Wychowanie fizyczne i sport w życiu Polonii mandżurskiej, ‘Prace Naukowe Akademii im. Jana Długosza. Pedagogika' 2011, 20, p. 354.

${ }^{131}$ J. Neja, op. cit., p. 70.

${ }^{132}$ CAW, Od. II Szt. Gł., ref. no. I.303.4.2015, lack of pagination.
} 
on November 22, 1940 in Harbin ${ }^{133}$. His wife and two daughters, however, left Manchuria in the following year. Identical measures were adopted in case of mining concession, with an area of 4,000 square kilometers ${ }^{134}$, belonging to Kazimierz Grochowski ${ }^{135}$.

Kazimierz Grochowski (1873-1937), who spent thirty years of his life in the Far East and kept close ties with Jack London, was a mining engineer and geologist, specializing in the search for gold and fossil fuels, but also an archaeologist, publicist, and social activist. Grochowski was born on 26th January 1873 in Kochawina near Ruda in Żydaczowski districk, attended junior high school in Jasło and Lviv, but due to the conspiracy activity against Tsarist Russia, he was forced to move to Cracow where he graduated from the local high school ${ }^{136}$. Furthermore, Grochowski studied successively at the University of Vienna as well as at the mining academies in Leoben, Pribram and Freiberg, obtaining the title of mining engineer in $1901^{137}$. Kazimierz Grochowski started his professional career within the Russian Empire in the Donets Black Coal Basin, however, in 1906 he decided to move to the Far East, where he initially made several shorter research expeditions across the area of present-day Primorsky Krai, working as a geologist, and later on throughout the island of Sakhalin ${ }^{138}$.

In 1909, Kazimierz Grochowski transferred to the vicinity of the Zeya River, and started working for the international concern called the Upper Amur Gold Mining Company, which at the time was a thriving joint stock company with French and German capital. The company was primarily dealing with a large-scale exploration as well as extraction of gold. He first became the head of the Department of Geological Research and, in 1911, the Deputy Director. Kazimierz Grochowski was not only looking for dispersed gold deposits, but also the primary deposits. From 1910 to 1914, Grochowski made four great mining journeys in eastern Siberia, beginning his new career as a gold prospector ${ }^{139}$. The routes of these expeditions ran through the areas of eastern Siberia, which until 1850 belonged to the Chinese Empire and, in geological terms, were still very poorly

${ }^{133}$ A. Winiarz, Główne kierunki, p. 43.

134 'Echo z Dalekiego Wschodu' 1939, 3, p. 17.

135 A. Aleksandrowicz, Mandżuria, jej przeszłość, teraźniejszość, kraj i ludzie, Warszawa 1937, p. 167.

136 E. Kajdański, Dzienniki syberyjskich podróży Kazimierza Grochowskiego, 1910-1914, Lublin 1986, p. 16.

137 R. Niedźwiedzki, Kazimierz Grochowski (1873-1937) - zapomniany badacz złota Syberii, ‘Przegląd Geologiczny' 2008, 56, 6, p. 461.

138 W. Mayer, History of Geoscience, London 2017, pp. 383-384.

139 J. Rowiński, J. Szczudlik, Z historii kontaktów polsko-chińskich (do 1945 roku), 'AzjaPacyfik' 2005, 8, pp. 26-27. 
investigated. In 1917, Grochowski was involved in a Swedish scientific expedition which conducted biological and geological research in western Mongolia. For a long time, using different methods, he sought deposits of gold, silver and other metals in the Amur River Basin. Nevertheless, the area was soon taken over by the Red Army, which led to his arrival in Harbin $^{140}$, where Grochowski actively engaged in social and economic life of the Polish community in Manchuria and Inner Mongolia, functioning as the editor of many local newspapers, such as Listy Polskie z Dalekiego Wschodu, Tygodnik Polski and Pamiętnik Harbińskiti1.

From 1923 to 1932, Kazimierz Grochowski lectured geography and history at the Henryk Sienkiewicz Secondary School in Harbin. What is more, in 1927, he was appointed head of the Henryk Sienkiewicz Secondary School by representatives of the Polish colony in Harbin. By 1934, Grochowski returned to Poland and took the position of the chief geologist within the coal mining company in Katowice. Three years later, he was appointed director of a gold mine in Manila. However, Kazimierz Grochowski died in Harbin on March 12, 1937, during the trip to the Philippines ${ }^{142}$.

Most importantly, in the summer of 1915, Kazimierz Grochowski decided to leave the Upper Amur Gold Mining Company, and less than a year later acquired a mining concession from the Inner Mongolian authorities on February 17, 1916. The concession, covering an area of approximately $4,000 \mathrm{~km}^{2}$ in Hulunbuir, was eventually approved by the Russian Vice-Consul in Hailar on 29th July 1916. Thus, Grochowski was granted the right to extract, along with other natural resources, oil, coal and gold, especially around the Khalkhyn Gol River in Inner Mongolia. Shortly after receiving concession rights, he was able to open a coal mine, quickly followed by salt and soda processing plants ${ }^{143}$. Unfortunately, Kazimierz Grochowski irretrievably lost his mining concession in $1936^{144}$, which was part of a wider plan, developed by the Japanese, for economic and military conquest of Manchuria, and consistently implemented at least since $1935^{145}$.

${ }^{140}$ N. Baron, P. Gatrell, Homelands: War, Population and Statehood in Eastern Europe and Russia, 1918-1924, London 2004, p. 152.

${ }^{141}$ E. Kajdański, Polacy na Dalekim, pp. 5-13.

142 Idem, Długi cień wielkiego muru. Jak Polacy odkrywali Chiny, Warszawa 2005, pp. 277-299.

${ }^{143}$ CAW, Od. II Szt. Gł., ref. no. I.303.4.2015, p. 7.

144 Similar measures were used against a number of European businessmen within other branches of Manchurian economy, such as soybean industry (Le soja: Nationalisation de cette industrie au Mandchoukouo, 'Revue Internationale des Produits Coloniaux et du Matérial Colonial' 1939, 14, 164-166, pp. 259-262).

${ }^{145}$ CAW, Od. II Szt. Gł., ref. no. I.303.4.3145, pp. 685-686. 


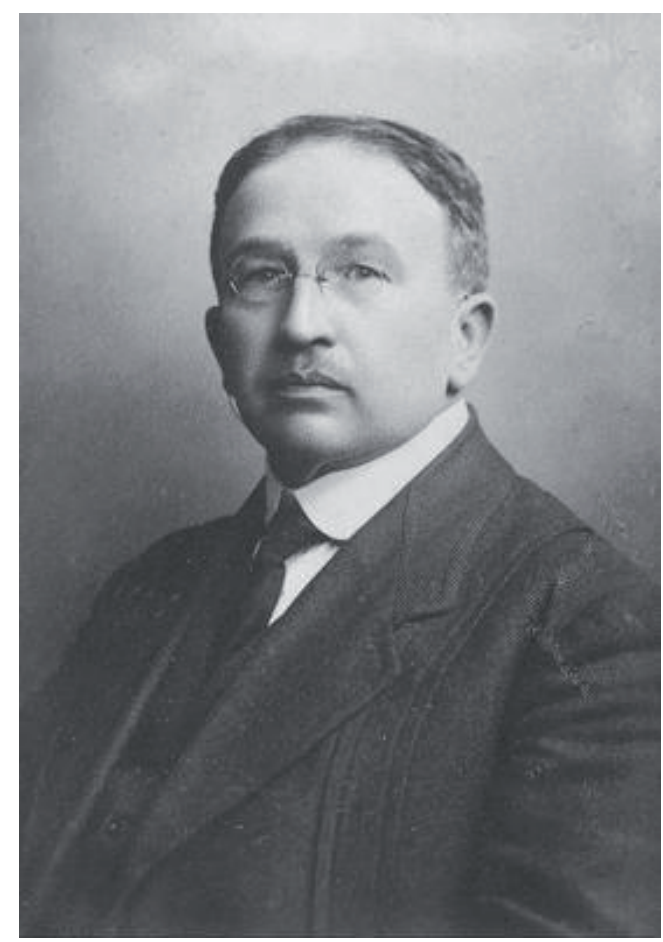

Figure 2: Kazimierz Grochowski, Harbin 1930

Source: Narodowe Archiwum Cyfrowe (National Digital Archives), ref. no. 1-Z-287

Owing to a great determination and ambition, both Władysław Kowalski as well as Kazimierz Grochowski made millions in business and consequently were in the group of the most influential entrepreneurs across Northeastern China. However, with the collapse of the largest Polish commercial establishments in the Far East, the majority of other Polish businessmen, merchants, traders and retailers in the borderland between northern China and southern Mongolia, who operated on a much smaller scale, suddenly found themselves in a very difficult position ${ }^{146}$. In the following years, some of them were forced to terminate their business activities in that part of Asia.

Therefore, many of them decided to leave Manchuria and Inner Mongolia in search of better business opportunities, in either southern

${ }^{146}$ Apart from Kowalski and Grochowski, the rest of Polish entrepreneurs did not stand out from the international mixture of enterprisers of Russian, Jewish, Armenian, Georgian or German origin (Е.А. Оглезнева, О динамике языковых ситуаций с участием славянских языков в хх в. (на материале дальнего востока россии и северо-востока китая), 'Библиотека журнала «Русин»' 2015, 3, рр. 113-114). 
China or other parts of the world, such as Northern America, Europe as well as Australia ${ }^{147}$. After 1936, the remaining representatives of the Polish community in Manchuria and Inner Mongolia were forced to live in a constantly deteriorating economic and social conditions ${ }^{148}$. In this way, only inconsiderable workshops and stores were left in the hands of the Poles, which sometimes led to disputes within the Polish enclave ${ }^{149}$. By 1945, all the major factories were dismantled and taken to the Soviet Union. In the following year, the region was taken over by the Chinese, meanwhile the Poles were deprived of all their possessions. As a result, the economic activity of Polish diaspora in Manchuria and Inner Mongolia came to an end, and therefore most of the Poles returned to Poland or left for the United States and Australia ${ }^{150}$.

\section{REFERENCES}

\section{Archival sources}

Archiwum Akt Nowych w Warszawie:

Kolonia Polska w Mandżurii

Konsulat Generalny RP w Charbinie

Ministerstwo Spraw Zagranicznych

Prezydium Rady Ministrów.

Archiwum Archidiecezjalne w Gnieźnie:

Archiwum Prymasa Polski.

Centralne Archiwum Wojskowe w Warszawie:

Materiały archiwalne z lat 1908-1939.

Książnica Pomorska w Szczecinie:

Zbiory specjalne.

Narodowe Archiwum Cyfrowe:

Koncern Ilustrowany Kurier Codzienny-Archiwum Ilustracji, ref. no. 1-Z-287.

Zbiory prywatne Jerzego Czajewskiego

Zbiory prywatne Leonarda Spychalskiego

\section{Printed sources}

Bureau of Foreign Commerce, Commercial Relations of the United States with Foreign Countries during the Year 1908, vol. 2, Washington 1909.

Chang Y., The Economic Development and Prospects of Inner Mongolia (Chahar, Suiyuan, and Ningsia), Shanghai 1933.

Economical Bureau of CER, The Chinese Eastern Railway and its Zone, Harbin 1923.

${ }^{147}$ It is worth mentioning that the first Polish settlers from Manchuria began heading for Australia in the early thirties of the twentieth century (AAG, APP, ref. no. 50, p. 63).

148 Spetnijmy czyn obywatelski wobec młodego pokolenia polskiego w Mandżurii, 'Ilustrowany Kuryer Codzienny' 1937, 210, p. 6; J. Misiurek, Z dziejów duszpasterstwa polonijnego w Harbinie (1926-1949), 'Studia Polonijne' 1977, 2, p. 308.

149 AAN, KPM, ref. no. 28, p. 9.

${ }^{150}$ E. Kajdański, Wspomnienia z mojej Atlantydy, p. 8. 
Hussey H., Manchukuo in Relation to World Peace. Things Not Told in the Report to the Commission of Enquiry, Geneva 1932.

Mikhoilov I.A., North Manchuria and the Chinese Eastern Railway, Harbin 1924.

Propaganda Corps, Imperial Japanese Forces, Significance of Greater East Asia Co-Prosperity Sphere, Manila 1942.

Sakatani Y., Clark G., Manchuria: A Survey of Its Economic Development, New York 1932.

Scherer J.A.B., Manchukuo. A Bird's-eye View, Tokyo 1933.

Stanford E., Atlas of the Chinese Empire Containing Separate Maps of the Eighteen Provinces of China Proper and the Four Great Dependencies, London 1908.

Young C.W., Japanese Jurisdiction in the South Manchuria Railway Areas, Baltimore 1931.

\section{Memoirs}

Dyboski R., Siedem lat w Rosji i na Syberii (1915-1921). Przygody i wrażenia, Warszawa 1922.

Kajdański E., Wspomnienia z mojej Atlantydy, Kraków 2013.

Khrushchev N.S., Khrushchev S., Memoirs of Nikita Khrushchev, 1953-1964, vol. 3, Statesman, Providence 2007.

Symonolewicz K., Miraże Mandżurskie, Warszawa 1932.

Tokarski J., Przez Syberię, Mandżurię i Japonię do brzegów Oceanu Spokojnego, Lwów 1911.

Vining L.E., Held by the Bolsheviks. The Diary of a British Officer in Russia, 1919-1920, London 1924.

\section{Periodicals}

'Biuletyn Polskiej Izby Handlowej w Harbinie' 1932, 5.

'Echo z Dalekiego Wschodu' 1934, 3.

Elliott M.C., The Limits of Tartary: Manchuria in Imperial and National Geographies, 'The Journal of Asian Studies', August 2000, 59, 3.

Frycz K., Wyrok Sądu Obywatelskiego, 'Listy Polskie z Dalekiego Wschodu' 7 VII 1918, 7.

Gieysztor J., Kolej Syberyjska, 'Kraj' 14 V 1897, 18.

Handel zagraniczny. Zapotrzebowanie towarów dla Mandżurii, 'Tygodnik Handlowy' 6 VI 1924, 23.

Ignacy Jasiukowicz. Źródła powodzenia, 'Przegląd Techniczny' 4 XII 1913, 49.

'Inżynier Kolejowy' 1926, 8-9.

Jabłońska A., Krąkowski K., Z dziejów Polonii harbińskiej, ‘Przegląd Orientalistyczny' 1961, 2.

'Journal of the Association of Chinese and American Engineers' 1924, 5.

Kusiak F., Osadnictwo reemigrantów z Mandżurii na ziemiach Polski Zachodniej i Pótnocnej w 1949 roku, 'Sobótka' 1994, 3-4.

Le soja: Nationalisation de cette industrie au Mandchoukouo, 'Revue Internationale des Produits Coloniaux et du Matérial Colonial’ 1939, 14, 164-166.

‘Listy Harbińskie' 1932, 5.

'Listy Harbińskie. Numer Noworoczny' 1 I 1932, 1.

Lubodziecki S., Polacy na Syberii w latach 1917-1920. Wspomnienia, 'Sybirak' 1934, 3/4.

Maynard L., Harbin. General Features, 'Special Consular Reports' 1913, 59.

Milling in Manchuria, 'American Miller and Processor' 1910, 38, 1-6.

Milling in Manchuria, 'The Northwestern Miller' 1908, 76.

Misiurek J., Z dziejów duszpasterstwa polonijnego w Harbinie (1926-1949), 'Studia Polonijne' 1977, 2.

Neja J., Polacy w Mandżurii, ‘Biuletyn Instytutu Pamięci Narodowej’ 2002, 3.

Neja J., Polski król Mandżurii, ‘Wprost' 2003, 9.

Niedźwiedzki R., Kazimierz Grochowski (1873-1937) - zapomniany badacz złota Syberii, 'Przegląd Geologiczny' 2008, 56, 6. 
Office of Strategic Services, Research and Analysis Branch, The Greater East Asia Co-Prosperity Sphere, 'Current Intelligence Study' 10 VIII 1945, 35.

‘Ojczyzna. Niezależny Tygodnik Demokratyczny' 16 XII 1945, 1.

'Pamiętnik Charbiński' 1923, 1.

Plan for Key Industries, 'Manchuria: A Semi-monthly Publication of the Manchuria Daily News' 1936, 1.

‘Praca. Pismo Postępowe Demokratyczne' 12 V 1918, 8.

Rowiński J., Szczudlik J., Z historii kontaktów polsko-chińskich (do 1945 roku), 'Azja-Pacyfik' $2005,8$.

Skóra W., Sytuacja materialna Polonii mandżurskiej w 1929 roku (w świetle raportu konsula RP Konstantego Symonolewicza), 'Przegląd Orientalistyczny' 2010, 3-4.

Spetnijmy czyn obywatelski wobec młodego pokolenia polskiego w Mandżurii, 'Ilustrowany Kuryer Codzienny' 1937, 210.

Stowarzyszenia polskie w Charbinie, 'Pamiętnik Charbiński' 1923, 1.

Symonolewicz K., O chunchuzach, 'Pamiętnik Charbiński' 1924, 2.

Syzdek W., Na mandżurskim szlaku, 'Życie Warszawy' 8 I 1988, 1.

'The Timberman' 1927, 28, 7-12.

'Tygodnik Polski' 9 IV 1939, 15.

'Tygodnik Polski'18 V 1941, 20.

‘Tygodnik Polski' 25 V 1941, 21.

Winiarz A., Wychowanie fizyczne i sport w życiu Polonii mandżurskiej, 'Prace Naukowe Akademii im. Jana Długosza. Pedagogika' 2011, 20.

Wojas B.Z., Dzieje Polonii Charbińskiej, 'Zeszyty Historyczne' 1974, 30 (250).

Wspomnienia pozgonne. Ś.p. Władysław Żukowski, ‘Przegląd Techniczny' 13 XII 1916, 49/50.

\section{Studies}

Aleksandrowicz A., Mandżuria, jej przeszłość, teraźniejszość, kraj i ludzie, Warszawa 1937.

Anuchin V.A., Geograficheskiye ocherki Man'chzhurii, Moskva 1948.

Bagiński H., Wojsko Polskie na Wschodzie 1914-1920, Warszawa 1921.

Baron N., Gatrell P., Homelands: War, Population and Statehood in Eastern Europe and Russia, 1918-1924, London 2004.

Bazylow L., Historia Mongolii, Wrocław 1981.

Ben-Canaan D., Grüner F., Prodöhl I., Entangled Histories. The Transcultural Past of Northeast China, New York 2014.

Białynia-Chłodecki J., Ćwierćwiecze kolonii polskiej w Charbinie na Dalekim Wschodzie, Lwów 1923. Brown K., A Biography of No Place. From Ethnic Borderland to Soviet Heartland, Cambridge 2003.

Cabanowski M., Tajemnice Mandżurii. Polacy w Harbinie, Warszawa 1993.

Cai Y., State and Laid-off Workers in Reform China: The Silence and Collective Action of the Retrenched, London 2006.

Deog K.Y., Kolonia polska w Mandżurii, Kraków 2001.

De Siebert B., Schreiner G.A., Entente Diplomacy and the World: Matrix of the History of Europe, 1909-1914, London 1921.

Doleżan W., Mandżurya. Opis kraju i ludzi, Warszawa 1904.

Dyboski R., Krzyżanowski L., Poland in World Civilization, New York 1950.

Dynowski W., Wspótczesna Mongolia, Wrocław 1968.

Grabowski E., Rozwój zaludnienia w Polsce w zestawieniu z innemi krajami. Według spisu z dnia 30-go września 1921 roku, Warszawa 1922.

Grochowski K., Polacy na Dalekim Wschodzie, Harbin 1928.

Hornbeck S.K., Contemporary Politics in the Far East, New York 1916.

Janik M., Dzieje Polaków na Syberii, Kraków 1928. 
Kajdański E., Długi cień wielkiego muru. Jak Polacy odkrywali Chiny, Warszawa 2005.

Kajdański E., Dzienniki syberyjskich podróży Kazimierza Grochowskiego, 1910-1914, Lublin 1986.

Kajdański E., Fort Grochowski, Olsztyn 1982.

Kajdański E., Korytarz. Burzliwe dzieje Kolei Wschodniochińskiej 1898-1998, Warszawa 2000.

Kajdański E., Polacy na Dalekim Wschodzie. Inżynier Kazimierz Grochowski, Czyngis-chan i złoto barona Ungerna, Warszawa 2014.

Kałuski M., Polacy w Chinach, Warszawa 2001.

Kawata T., Glimpses of East Asia, Tokyo 1928.

Kizilov M., The Sons of Scripture. The Karaites in Poland and Lithuania in the Twentieth Century, Warsaw 2015.

Komorowski W., Daleki Wschód w międzynarodowej polityce gospodarczej, Warszawa 1931.

Korff S.A., Russia in the Far East, Washington 1921.

Krahmer G., Syberya i znaczenie wielkiej kolei syberyjskiej, Warszawa 1898.

Kuromiya H., Pepłoński A., Między Warszawa a Tokio. Polsko-japońska wspótpraca wywiadowcza 1904-1944, Toruń 2009.

Lattimore O., Studies in Frontier History: Collected Papers, 1928-1958, London 1962.

Lin M.H., International Law and the Undeclared War, New York 1937.

Melikhov G.V., Belyy Kharbin: Seredina 20-kh, Moskva 2003.

Melikhov G.V., Man'chzhuriya dalekaya i blizkaya, Moskva 1991.

Mayer W., History of Geoscience, London 2017.

Meyer M., In Manchuria: A Village Called Wasteland and the Transformation of Rural China, New York 2015.

Montague Bell H.T., Woodhead H.G.W., The China Year Book 1919, London 1919.

Moustafine, Secrets and Spies. The Harbin Files, London 2002.

Neja J., Harbin jako przestrzeń życia i działalności Polonii mandżurskiej, in: Polskie ślady na Dalekim Wschodzie. Polacy w Harbinie, ed. A. Furier, Szczecin 2008.

Oglezneva Ye.A., Odinamike yazykovykh situatsiy s uchastiyem slavyanskikh yazykov v XX v. (na materiale dal'nego vostoka rossii i severo-vostoka kitaya), 'Biblioteka zhurnala «Rusin»' $2015,3$.

Olson J.S., Historical Dictionary of the Great Depression, 1929-1940, Westport 2001.

Paine S.C. M., Imperial Rivals. China, Russia, and Their Disputed Frontier, Armonk 1996.

Patrikeeff F., Russian Politics in Exile. The Northeast Asian Balance of Power, 1924-1931, Oxford 2002.

Petrenko A., V.F.Koval'skiy - vydayushchiysya khozyaystvennik Man'chzhurii, 'Na sopkakh Man'chzhurii' 1996, 34.

Petrov V.P., Gorod na Sungari, Vashington 1984.

Quested R.K.I., "Matey" Imperialists: the Tsarist Russians in Manchuria 1895-1917, Hong Kong 1982.

Ristaino M.R., Port of Last Resort. The Diaspora Communities of Shanghai, Stanford 2001.

Scott-Keltie J., Howarth O.J.R., History of Geography, London 1913.

Seaman L.L., From Tokio through Manchuria with the Japanese, London 1905.

Shteynfel'd N.P., Chto delat's Man'chzhuriyey?, Kharbin 1913.

Shteynfel'd N.P., My i yapontsy $v$ Man'chzhurii, Kharbin 1913.

Shteynfel'd N.P., Prichiny'upadka russkoy torgovli v Mongolii, 'Promyshlennost' i torgovlya' 1911, 21.

Shteynfel'd N.P., Russkaya torgovlya v Mongolii v kharakteristike mestnogo kupechestva, 'Vestnik Azii' 1909, 2.

Shukman H., The Blackwell Encyclopedia of the Russian Revolution, Oxford 1988.

Skóra W., Placówki MSZ Drugiej Rzeczypospolitej w Harbinie w latach 1920-1941 na tle dziejów Chin i Mandżurii (Mandżukuo). Szkic do problemu, in: Na szlakach dwóch światów. Studia 
ofiarowane Profesorowi Jerzemu Hauzińskiemu w 45 lecie pracy naukowej i dydaktycznej, ed. A. Teterycz-Puzio, Słupsk 2016.

Stephan J., The Russian Far East. A History, Stanford 1994.

Tang P.S.H., Russian and Soviet Policy in Manchuria and Outer Mongolia, 1911-1931, Durham 1959.

Theiss W., Dzieci syberyjskie. Dzieje polskich dzieci repatriowanych z Syberii i Mandżurii w latach 1919-1923, Warszawa 1992.

Tishenko P.S., Kharbinskaya starina, Kharbin 1936.

Trubetskoy G., Kitay, Yaponiya i Rossiya, 'Moskovskiyy ezhenedel'nik' 1909, 37.

Victoir L., Zatsepine V., Harbin to Hanoi. The Colonial Built Environment in Asia, 1840-1940, Hong Kong 2013.

Volpicelli V., Russia on the Pacific. And the Siberian Railway, London 1899.

Wagel S.R., Finance in China, Shanghai 1914.

Wasilewska-Dobkowska J., Sztuka Chin, Warszawa 2009.

Williams A., The Romance of Modern Engineering. Containing Interesting Descriptions in Non-Technical Language of the Nile Dam, the Panama Canal, the Tower Bridge, the Brooklyn Bridge, the Trans-Siberian Railway, the Niagara Falls Power Bermuda Floating Dock, Etc, London 1912.

Winiarz A., Główne kierunki i formy aktywności Polaków w Mandżurii w latach 1897-1949, in: Polskie ślady na Dalekim Wschodzie. Polacy w Harbinie, ed. A. Furier, Szczecin 2008.

Winiarz A., Polska diaspora w Mandżurii, in: Polska diaspora, ed. A. Walaszek, Kraków 2001. Woodhead H.G.W., Montague Bell H.T., The China Year Book 1914, London 1914.

Woodhead H.G.W., Montague Bell H.T., The China Year Book 1921, Tientsin 1922.

Yakhontoff V.A., Eyes on Japan, New York 1936.

Yust W., Britannica Book of the Year 1944, London 1944.

\section{STRESZCZENIE}

Daleki Wschód, w tym Mongolia Wewnętrzna i Mandżuria, przez ponad półtora wieku był miejscem niekończącej się tułaczki i długoletniej zsyłki Polaków, których rosyjska tyrania wygnała na nieznane odludzia. Jednocześnie wielu z nich przyczyniło się do rozwoju gospodarczego tej części Azji. W miarę upływu czasu znacząca ilość Polaków częściowo zesłańców politycznych, a częściowo dobrowolnych emigrantów obdarzonych duchem przedsiębiorczości - dorobiła się fortuny i zarazem przyczyniła się do budowy dużych manufaktur, zarówno na terenie słabo zaludnionych stepów Mongolii Wewnętrznej, jak i rozległych lasów północno-wschodnich Chin. Przykładem tego mogą być losy przedsiębiorcy Władysława Kowalskiego (1870-1940) i inżyniera Kazimierza Grochowskiego (1873-1937), którzy byli wybitnymi przedstawicielami polskiej diaspory w Mandżurii i Mongolii Wewnętrznej.

Kowalski, powszechnie szanowany przez inne diaspory $\mathrm{w}$ regionie, zgromadził olbrzymi majątek i został jednym z najbardziej wpływowych fabrykantów, a także filantropów na obszarze Mandżurii. Natomiast Grochowski nadzorował badania geologiczne nad Amurem, na Sachalinie oraz w Mongolii Wewnętrznej, a także znalazł złoża ropy naftowej w Mandżurii. Obecność Polonii w Mandżurii i Mongolii Wewnętrznej ściśle wiązała się z budową Kolei Wschodniochińskiej, łączącej Syberię z północnymi Chinami i przyciągającej tysiące osób z najdalszych krańców Imperium Rosyjskiego w okolice słabo rozpoznanego pasa pogranicznego Rosji, Mongolii Wewnętrznej i Mandżurii.

Słowa kluczowe: Diaspora polska, Mandżuria, Mongolia Wewnętrzna 


\section{ABOUT THE AUTHOR}

Mariusz Borysiewicz - doctoral student at the Institute of History and Politology at the Faculty of Philology and History at the Pomeranian University in Słupsk. He deals with the history of international relations, Polish diplomacy and foreign relations. The scope of his academic interests include the activity of the Polish consular offices operating in the Far East, and the activity of Polish communities in China and Manchuria. E-mail: mariuszbory@wp.pl. 